Microrefugia, Small Scale Ice Age Forest Remnants

Author(s): M. E. Leal

Source: Systematics and Geography of Plants, Vol. 71, No. 2, Plant Systematics and

Phytogeography for the Understanding of African Biodiversity, (2001), pp. 1073-1077

Published by: National Botanic Garden of Belgium

Stable URL: http://www.jstor.org/stable/3668739

Accessed: 22/05/2008 06:59

Your use of the JSTOR archive indicates your acceptance of JSTOR's Terms and Conditions of Use, available at http://www.jstor.org/page/info/about/policies/terms.jsp. JSTOR's Terms and Conditions of Use provides, in part, that unless you have obtained prior permission, you may not download an entire issue of a journal or multiple copies of articles, and you may use content in the JSTOR archive only for your personal, non-commercial use.

Please contact the publisher regarding any further use of this work. Publisher contact information may be obtained at http://www.jstor.org/action/showPublisher?publisherCode=nbgb.

Each copy of any part of a JSTOR transmission must contain the same copyright notice that appears on the screen or printed page of such transmission.

JSTOR is a not-for-profit organization founded in 1995 to build trusted digital archives for scholarship. We enable the scholarly community to preserve their work and the materials they rely upon, and to build a common research platform that promotes the discovery and use of these resources. For more information about JSTOR, please contact support@ jstor.org. 


\title{
Microrefugia, small scale ice age forest remnants
}

\author{
M.E. Leal \\ Laboratory of Plant Taxonomy, Wageningen University, General Foulkesweg 37, 6700 ED Wageningen, The Netherlands
} [Miguel.Leal@BiosysNhn.DPW.wau.nl]

\begin{abstract}
In this study the possibility of rainforest outside the postulated refuge areas is explored by assessing the presence of rainforest Caesalpinioideae in Lopé forest savannah mosaic in Gabon. In this dry area twenty-six tree species of this subfamily were located. Their physiological ability to cope with drought stress and their impossible migration from the nearest postulated refuge area strongly suggests that these species remained in the Lopé area during the last ice age. Extrapolating this observation and incorporating all refuge indicator species outside the postulated refuge area, supports the idea that small fragments of forest persisted during the last ice age acting as microrefugia.
\end{abstract}

Key words: rainforest, Pleistocene forest refuge theory, ice age, Caesalpinioideae, microrefugia, Gabon

Résumé. - Les micro-refuges, reliques forestières à petite échelle de l'époque glaciaire. L'existence possible de la forêt ombrophile à l'extérieur des aires-refuges présumées est envisagée dans cette étude par l'examen de la présence des Caesalpinioideae dans la mosaïque forêt-savane à Lopé au Gabon. Dans cette région sèche, vingt-six espèces d'arbres de cette sous-famille ont été signalées. Leur capacité physiologique à faire face au stress hydrique et l'impossibilité qu'elles aient pu migrer à partir de l'aire-refuge présumée la plus proche suggèrent que ces espèces ont dû subsister dans la région de Lopé au cours de la dernière période glaciaire. L'extrapolation de cette observation et la prise en compte de toutes les espèces indicatrices d'un refuge hors de l'aire-refuge présumée conduisent à postuler que de petits fragments de forêts ont persisté au cours de la dernière période glaciaire, constituant des micro-refuges. Traduit par le journal.

\section{Introduction}

The Pleistocene Forest Refuge Theory states that current centres of biodiversity and endemism in the African rainforest are the locations where fragments of rainforest persisted during ice ages, so-called forest refugia. These forest refugia are placed along the continental edges of West Africa and western Central Africa, at the foothills west of the Rift Mountains and in the centre of the Congo Basin (fig.1) (Maley 1987, Sosef 1996, Van Rompaey 1996, Colyn et al. 1991, Ndjele 1988). Although the strong reduction of rainforest involved is met with some hesitation, the loss of the rainforest should not be taken too lightly, since even western Cameroon, the wettest area in Africa had been affected and became largely deforested (Maley \& Brenac 1998).

E. Robbrecht, J. Degreef \& I. Friis (eds.) Plant systematics and phytogeography for the understanding of African biodiversity. Proceedings of the XVIth AETFAT Congress, held in 2000 at the National Botanic Garden of Belgium. 
Pollen records and fossil deposits are very restricted in the African rainforest and the best evidence at present is afforded by the distribution of plant species. Knowing that during the last ice age species were aggregated into smaller forest pockets, it is not implausible that with amelioration of climatic conditions a species diversity gradient became established within the expanded rainforest as a result of differences in dispersal rate between species. However, opinions remain divided whether centres of biodiversity are historically determined or determined by present-day ecological factors, since many of these centres are situated in geomorphologically heterogeneous areas, which are associated with high levels of niche-differentiation.

A way to bypass this impasse is by focussing on rainforest species with a restricted seed dispersal mechanism, eliminating the possibility of a restricting ecological factor or niche. Species of Begonia sect. Loasibegonia and sect. Scutobegonia are such plants and their presence outside the postulated forest refugia (Sosef 1996) strongly suggests that more forest existed than is presently proposed in the Pleistocene forest refuge theory. This study sets out to test the possibility of rainforest outside the postulated refuge areas during the last ice age, i.e. rainforest species surviving in dry areas.

\section{Rationale}

Caesalpinioideae with a ballistic seed dispersal mechanism have been chosen as a tool to test this possibility, because they have the unique combination of being well distributed over the African rainforest and of dispersing very slowly. Their wide distribution creates the possibility to extrapolate and to make statements on a wider scale and their slow range expansion makes them forest refuge indicators.

Range expansion is slow because seeds are projected only over a few tens of meters per reproductive season (Van der Burgt 1997) and secondary dispersal by animals has proven unlikely (Hughes $e t$ al. 1994, Tutin et al. 1997). The ectomycorrhizal character of many Caesalpinioideae (Newberry et al. 1988) may also inhibit the advance by occasional long-distance events, since seedlings need to be near the mother tree for ectomycorrhizal infection. Consequently once they have gone locally extinct due to a rainforest reduction as during the last ice age they remain locally extinct for some time. These characteristics make them indicative for stable forest areas, or forest refugia.

This study deals with this matter, under the assumption that tree species with longevity, like the Caesalpinioideae, have had the same physiological range and limitations during the last ice age as they have today. Assuming this it gives the opportunity to study species in present-day environmental conditions, which resemble closely the conditions during the last ice age. The major factor reducing rainforest surface during the last ice age was increased drought (e.g. Maley 1989). There are Caesalpinioideae, which are adapted to dry conditions. So the question here is, are rainforest Caesalpinioideae able to live under dry conditions.

\section{Study site}

The Lopé forest savannah mosaic in central Gabon (fig. 1) is a dry area, which forms a gap in the rainforest as the result of a climatic anomaly. The mean annual rainfall is $1499 \mathrm{~mm}$ (yrs 1984-2000) and the area is dominated by grassland, which is maintained by annual fires. Fire, however, does not destroy the existing forest, it only prevents the establishment of new forest (personal observation; Kellman \& Meave 1997). The presence of grassland has been dated back as far as 10,000 BP (Tutin \& White 1998). The whole Lopé forest savannah area was inventoried for the presence of Caesalpinioideae. Each species was checked for its true rainforest character. 


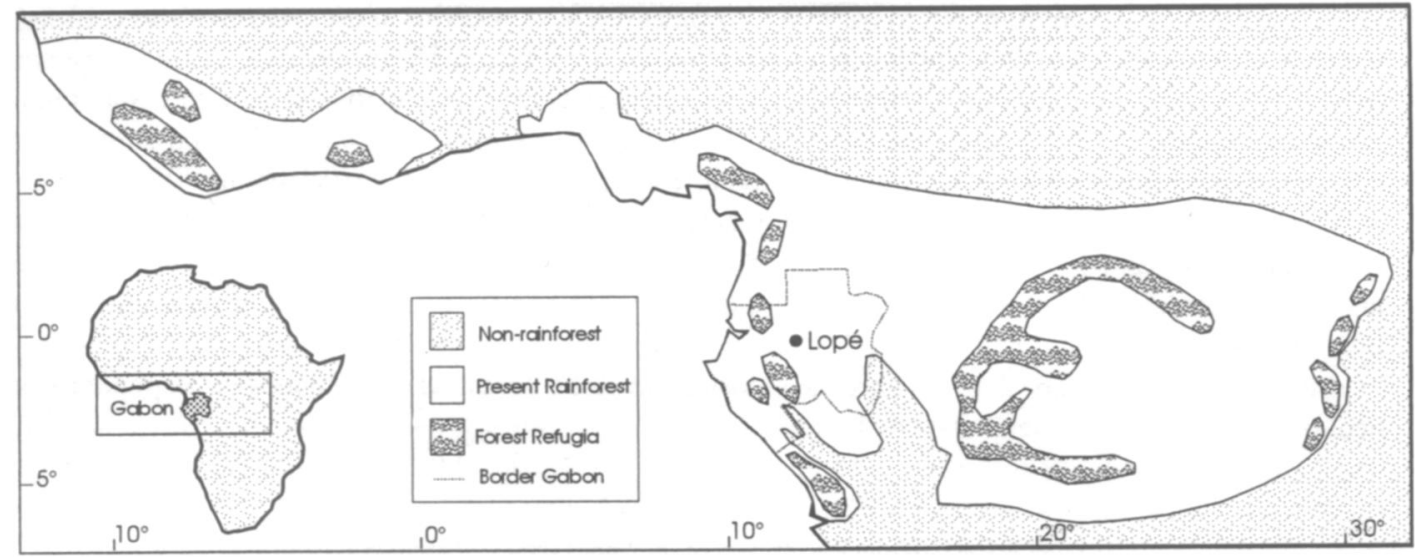

Figure 1. The postulated forest refuge areas within the present-day rainforest (modified after Malcy 1987).

\section{Results and discussion}

Twenty-six species with a ballistic dispersal mechanism were located (table 1). These species are fairly to well distributed over the rainforest or part of it (Aubréville 1968, Caballé 1987, Wieringa 1999). They are not present in deciduous forests (Letouzey 1968) or in woodland outside the rain forest. They are all considered rainforest tree species.

Diversity and abundance of the Caesalpinioideae varied over the mosaic, but levels were highest at places where moisture is elevated by local circumstances, excluding marshes and other long-term inundated areas. Although mean annual rainfall is $1499 \mathrm{~mm}$, annual minima have been close to 1200 $\mathrm{mm}$. So these Caesalpinioideae are rainforest tree species, which in a dry region are restricted to the moister places where they are physiologically able to cope with a considerable amount of drought stress. The drought stress these species are now experiencing is more then during the last ice age when temperatures were lower and evaporation was not as strong as today. This proves that these rainforest trees did not necessarily have to become locally extinct when deteriorating climatic conditions reduced the rainforest habitat.

An estimation of dispersal rate is needed to establish whether or not these species could have reached the outer limits of their present distribution from one of the refuge areas since the last ice age. Measurements on seed dispersal distances have been done on the Caesalpinioid tree species Tetraberlinia moreliana Aubrév. (Van der Burgt 1997), which is representative for this kind of seed dispersal. The maximum seed dispersal distance was $60 \mathrm{~m}$ from a $40 \mathrm{~m}$ tall tree; a record for a seed ballistically dispersed (Van der Burgt 1997). As a non-pioneer tree species, a considerable amount of time will pass before a seed has become reproductive and disperses the next generation. So range expansion per generation for these Caesalpinioideae is slow, i.e. a few tens of meters. The time involved for these Caesalpinioideae to reach their reproductive phase is unknown, but it can be calculated how much it should have taken for them to reach at least the Lopé area from the nearest postulated refuge area.

The nearest postulated refuge area is the Massif du Chaillu, $100 \mathrm{~km}$ further south. For the 26 species to have reached the Lopé forest savannah mosaic they must have covered $100 \mathrm{~km}$ in 18,000 years (the time since the height of the last ice age), i.e. a range expansion of $5.6 \mathrm{~m}$ per year. For a nonpioneer tree, like Tetraberlinia moreliana this would mean that it had to reach reproductive age in 
eleven years and grown $40 \mathrm{~m}$ tall to be able to project the next generation $60 \mathrm{~m}$ further away. Eleven years is an unlikely short time for a non-pioneer tree to have become reproductive. A more realistic time is 30 years and consequently this results in a dispersal rate of $2 \mathrm{~m}$ per year with a maximum range expansion of $36 \mathrm{~km}$ since the height of the last ice age. Considering this slow and short range expansion, migration from the nearest postulated forest refuge area is not very plausible.

Occasional long-distance seed dispersal events are not considered here as very likely, because secondary dispersal by animals has not been observed (Hughes et al.1997, Tutin et al. 1997). Also the need for ectomycoryzal infection by the mother tree may hamper the establishment of seedlings over a long distance.

Besides, it is unlikely that 26 species reached the Lopé forest savannah mosaic depending on occasional long-distance seed dispersal only.

Table 1. Caesalpinioideae present in the Lopé forest savannah mosaic.

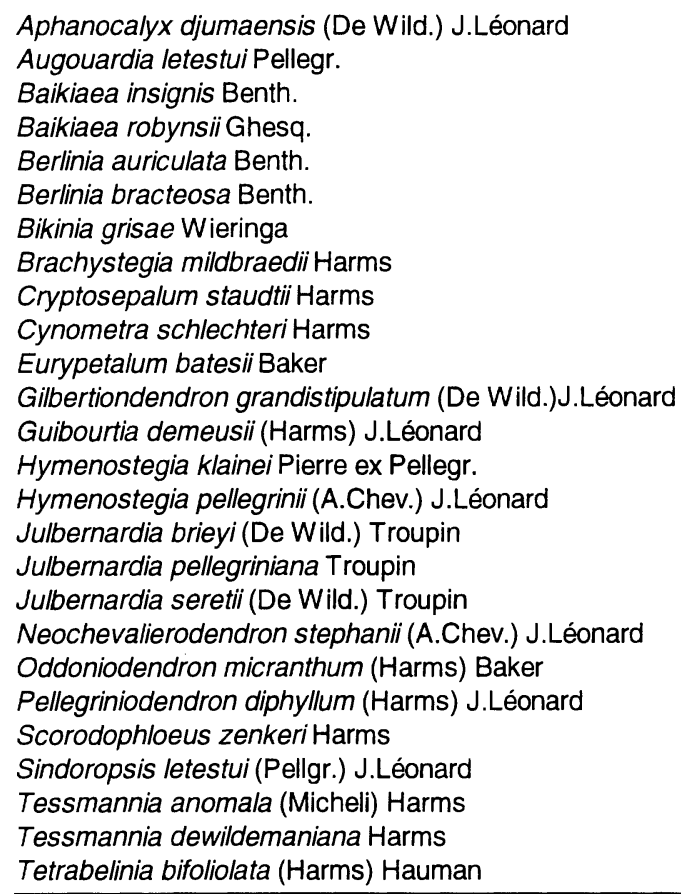

\section{Conclusions}

Since migration from the nearest postulated forest refuge is not very plausible and since these species have proven to be able to cope with a considerable amount of drought stress, it is much more plausible that they survived the last ice age in situ, i.e. the Lopé forest savannah mosaic. Also the presence of refuge Begonias in the Lopé forest savannah mosaic supports the probability that rainforest persisted during the last ice age.

The 26 refuge Caesalpinioideae and the two refuge Begonias are not restricted to the Lopé forest savannah mosaic, but are fairly to well distributed over the African rain forest and under much wetter conditions. Deterioration of these wet conditions and reduction of the rainforest habitat as during the 
last ice age does not necessary have to lead to their local extinction as their presence in the Lopé area has proven.

There are many more refuge Begonias not present in the Lopé area, but outside the postulated forest refugia and there are also many more refuge Caesalpinioideae with a distribution beyond the distance of $36 \mathrm{~km}$ from the nearest postulated forest refuge areas (e.g. see distribution maps in Wieringa 1999). All these refuge indicator plants together strongly indicate that outside the postulated large areas of continuous forest, (macro)refugia, small patches of forest must have remained, acting as small scale refuge areas or microrefugia.

Acknowledgements. - I am grateful to the Ministry of the Eaux et Fôrets for permission to work in the Lopé Reserve, and the research station CIRMF/WCS and research staff for logistics, accommodation and discussions. I thank K. Abernethy, B. van Gemerden, M. Sosef and one anonymous reviewer for their comments and suggestions. Financial support for the work was provided by the Netherlands Foundation of the Advancement of Tropical Research (WOTRO).

\section{References}

Aubréville A. (1968) Légumineuses-Caesalpinioidées. Flore du Gabon 15. Paris, Mus. Nat. d'Hist. Nat. Caballé G. (1978) Essai sur la géographie forestière du Gabon. Adansonia, sér.2 17:425-440.

Colyn M., Gautier-Hion A. \& Verheven W. (1991) A re-appraisal of palaeoenvironment history in Central Africa: evidence for a major fluvial refuge in the Zaïre Basin. J. Biogeogr. 18: 403-407.

Kellman M. \& Meave J. (1997) Fire in the tropical gallery forest of Belize. J. Biogeogr. 24: 23-34.

Letouzey R. (1968) Étude phytogéographique du Cameroun. Lechevalier, Paris.

Maley J. (1987) Fragmentation de la forêt dense humide africaine et extension des biotopes montagnards au quaternaire récent: nouvelles données polliniques et chronologiques. Implications paléoclimatiques et biogéographiques. Palaeoecology of Africa 18: 307-334.

Maley J. (1989) Late Quaternary changes in the African rainforest. In M. Leinen \& M. Sarnthein (eds.) Palaeoclimatology and Palaeometeorology; modern and past patterns of global transport: 585-616. London, Kluwer Academic Publishers.

Maley J. \& Brenac P. (1998) Vegetation dynamics, palaeoenvironments and climatic changes in the forest of west Cameroon during the last 28,000 years BP. Rev. Palaeobot. Palynol. 99: 157-187.

Ndjele M. (1988) Principales distributions obtenues par l'analyse factorielle des éléments phytogéographiques présumés endémiques dans la flore du Zaïre. 1985 AETFAT proceedings-contributed papers. Monogr. Syst. Bot. 25: 631-638.

Sosef M.S.M. (1996) Refuge Begonias and African rain forest refuges: general aspects and recent progress In L.J.G. van der Maesen, X.M. van der Burgt \& J.M. van Medenbach de Rooy (eds.) The biodiversity of African Plants: 602-611. Dordrecht, Kluwer Academic Publishers.

Tutin C.E.G. \& White L.J.T. (1998) Primates, phenology and frugivory: present, past and future patterns in the Lopé Reserve, Gabon. In D.M. Newberry, H.H.T. Prins \& N. Brown (eds.) Dynamics of populations and communities in the tropics: 135-146. Brit. Ecol. Soc. Symposium 37. Oxford, Blackwell Scientific.

Tutin C.E.G., Ham R.M., White L.J.T. \& Harrison M.J.S. (1997) The primate community of the Lopé Reserve in central Gabon: diets, responses to fruit scarcity and effects on biomass. Amer. J. Primatol. 42: 1-24.

Van der Burgt X.M. (1997) Explosive seed dispersal of the rainforest tree Tetraberlinia moreliana (LeguminosaeCaesalpinioideae) in Gabon. J. Trop. Ecol. 13: 145-151.

Van Rompaey R.S.A.R. (1996) Rainforestrefugia in Liberia. In L.J.G. van der Maesen, X.M. van der Burgt \& J.M. van Medenbach de Rooy (eds.) The biodiversity of African Plants: 624-628. Dordrecht, Kluwer Academic Publishers.

Wieringa J.J. (1999) Monopetalanthus exit. A systematic study of Aphanocalyx, Bikinia, Icuria, Michelsonia and Tetraberlinia (Leguminosae, Caesalpinioideae). Wageningen, $\mathrm{PhD}$ thesis, Wageningen Agric. Univ. Papers.

Manuscript received November 2000; accepted in revised version March 2001. 